\title{
Postopek sprejemanja predpisov
}

UDK 342 (094.79)

\author{
Rajko Pirnat \\ Pravna fakulteta Univerze $v$ Ljubljani \\ Inštitut za javno upravo pri Pravni fakulteti
}

\begin{abstract}
IZVLEČEK
Postopek sprejemanja predpisov postaja $v$ zadnjem času zelo aktualno vprašanje $v$ slovenskem pravu. Avtor najprej obravnava razloge za to, nato pa kratko prikaže splošni postopek sprejemanja zveznih predpisov v ZDA, pri čemer je poudarek zlasti na $t$. $i$. postopku "notice and comment", imenovanem tudi neformalni postopek. Zadnji del članka je namenjen oblikovanju nekaterih temeljnih elementov morebitnega splošnega postopka sprejemanja upravnih predpisov v slovenskem pravu. Ti elementi se morajo nanašati na naslednja vprašanja: kateri predpisi naj bodo podvrženi temu postopku, kaj mora vsebovati objava predloga predpisa, kako naj bo organizirano zbiranje pripomb in predlogov javnosti in kakšne so dolžnosti upravnega organa $v$ zvezi s sprejemom in objavo predpisa.
\end{abstract}

Ključne besede: elementi sprejemanja upravnih predpisov, primerjalno-pravni postopkovni vidiki, postopek sprejemanja prostorskih aktov

\section{Uvod}

Ureditev postopka sprejemanja postaja tudi $\vee$ slovenskem pravnem sistemu $\vee$ zadnjem času aktualna. Glavni razlog vidim v naraščanju obsega regulativne dejavnosti uprave. Zakoni lahko družbena razmerja urejajo le zelo splošno, kar zahteva, da upravni predpisi $v$ veliki meri ustvarjajo nove pravne norme in uvajajo ali urejajo pravice in obveznosti, ki jih ni v zakonu ali jih je mogoče iz zakona interpretirati le z zelo široko razlago. S potrebo po vključevanju zahtev evropskega prava $v$ slovenski pravni red se ta regulativna dejavnost izredno povečuje in pospešuje.

Vsebinska oziroma materialna zakonitost predpisov ima pri tem svoje meje. Njen namen je zagotoviti ravno tisto, kar postaja $\vee$ sodobnih razmerah čedalje obsežnejšega upravnega normiranja vse težje - vsebinsko skladnost predpisa z zakonom, kar seveda terja, da zakon vsebuje vsaj v temelju tudi vse norme podzakonskega predpisa. S tem se preobremenjuje državni zbor, ki mora sprejemati obsežne zakone z mnogimi podrobnostmi, mora pa jih tudi pogosto spreminjati. $V$ parlamentu se zato preveč odloča o podrobnostih, ki jih včasih poslanci strokovno ne morejo obvladati, hkrati pa se nepotrebno politizirajo strokovna vprašanja. Seveda v nobenem primeru teh besed ni treba razumeti tako, da se zavzemam za zmanjšanje relativno strogih kriterijev 
vsebinske zakonitosti predpisov, ki jih je oblikovalo ustavno sodišče, ampak želim zgolj opozoriti na njihove meje.

Ureditev postopka sprejemanja upravnih predpisov je možna in praktična rešitev težav, ki nastajajo z vse obsežnejšim upravnim normiranjem. Vsebinska zakonitost ni sama sebi namen, ampak mora zagotoviti skladnost upravnih predpisov z zakonom, ki je $v$ demokratični državi vsaj $\vee$ načelu rezultat demokratično izražene volje suverenega ljudstva. Čeprav se seveda zavedam, da je resničnost daleč od tega in da je zakon praviloma rezultat političnega procesa z vsemi kompromisi in drugimi načini reševanja konfliktov, pa mu ta politični proces daje legitimnost. To je mogoče zagotoviti tudi s tem, da se demokratični politični proces prenese še na raven sprejemanja upravnih predpisov in se tako omogočita $\vee$ tem postopku predstavitev tistih interesov, ki so relevantni za vsebino predpisa, in demokratično reševanje konfliktov med temi interesi in javnim interesom ter tudi med njimi samimi. 1

Zavedam se, da v tej smeri ležijo številne pasti, največja prav v strukturi države, ki izrecno temelji na delitvi oblasti.2 Razmerje med zakonodajno in izvršilno oblastjo temelji $\vee$ marsičem na tem, da prva omejuje drugo z zakoni in da mora izvršilna oblast ravnati $\vee$ mejah in na podlagi zakona. Če izvršilna oblast utemeljuje legitimnost svojih odločitev, zlasti tistih $\vee$ obliki splošnih aktov, neposredno na demokratičnem političnem procesu, s tem pridobi nekatere atribute zakonodajne oblasti. Vendar je t. i. "delegirana zakonodaja"3 nujnost ne le sodobnih upravnih sistemov, ampak tudi tistih iz bližnje preteklosti. Sprejeti je treba dejstvo, da ima neposredno omejevanje vsebine odločanja izvršilne oblasti z zakoni svoje meje in da je treba z zakonom bolj omejiti način odločanja. Poiskati je treba torej izvedljivo ravnotežje med vsebinsko in procesno zakonitostjo, kar je še vedno $v$ skladu z jedrom ideje delitve oblasti, s sistemom omejitev in ravnotežij (checks and balances).

Iskanju praktičnih rešitev tega ravnotežja in izvedljivih modelov postopka za sprejemanje upravnih predpisov je namenjen ta prispevek. Razmišljanja v glavnem temeljijo na izkušnjah ameriškega prava, ki ima edino izdelano precej dosleden postopek sprejemanja predpisov.

1 Na tem mestu kaže omeniti Webra, ki opozarja, da pri oblikovanju sodobnega prava prevladujejo vrednostni elementi (torej interesi), zaradi česar je pogosto manj racionalno, kar spet lahko zmanjša njegovo legitimnost; to je še posebno problem pri splošnih upravnih aktih, ki naj bi bili racionalen rezultat delovanja uprave kot racionalne birokratske organizacije; glej Weber, Max: On Charisma and Institution Building, Chicago 1968, str. 114-115.

2 To izrecno določa 3. člen slovenske ustave.

3 Izraz je prevod iz ameriške pravne doktrine (delegation of legislative power) in se $v$ našem pravu ne uporablja. Kljub temu ga na tem mestu uporabljamo, saj jasno opisuje problem, ki je posebno izražen v ameriškem pravu zaradi velikega poudarjanja delitve oblasti v ZDA. Dve stoletji so ameriška sodišča sicer ves čas trdila, da delegacija zakonodajne oblasti ni mogoča, vendar so delegirano zakonodajo čedalje bolj dopuščala. Glej Gellhorn, Walter, in Byse, Clark: Administrative Law, Cases and Comments, New York 1970; str. 48-68. 
Rajko Pirnat

Postopek sprejemanja predpisov

\section{Kratek prikaz ameriške ureditve sprejemanja zveznih upravnih predpisov}

Ameriško pravo je torej eno redkih, ki je razvilo splošen postopek sprejemanja upravnih predpisov, ni pa popolnoma jasno, kateri razlogi so pripeljali do tega, saj je bilo stališče sodne prakse ves čas, da se t. i. klavzula ameriške ustave due process of law ne uporablja oziroma ne nanaša na sprejemanje predpisov. ${ }^{\mathbf{4}}$ Kljub temu je velik obseg izdajanja upravnih predpisov (regulativna dejavnost), zlasti po veliki gospodarski krizi v začetku 30. let, pripeljal do postopne uveljavitve nekaterih procesnih določb tudi za izdajanje upravnih predpisov.

Začetek in še vedno temelj te procesne ureditve je $v$ Administrative Procedure Act (APA) iz leta 1946, ${ }^{\mathbf{5}}$ ki splošno ureja tako postopek izdajanja splošnih upravnih aktov (rulemaking) kot tudi postopek odločanja $\vee$ posamičnih stvareh (adjudication). Taka rešitev izhaja iz stališča, da ni bistvene razlike med odločanjem $v$ posamičnih primerih in izdajanjem splošnih pravnih aktov, saj je zaradi precedenčne narave posamičnih aktov oboje "ustvarjanje prava". 6 Vendarle pa so razlike in čeprav sta oba postopka urejena $v$ istem zakonu, imata le malo skupnega, zato bo $v$ nadaljevanju obravnavan le postopek izdajanja upravnih predpisov.

Splošni upravni akt (rule) je v smislu APA vsaka izjava upravnega organa, ki naj se uporablja splošno ali v posamičnem primeru in z bodočim učinkovanjem, s katero se izvršuje, interpretira ali predpisuje pravo oziroma politika, ${ }^{\mathbf{7}}$ kar je nedvomno širša opredelitev kot $v$ slovenskem pravu. Najprej se očitno nanaša tudi na posamične in ne le splošne abstraktne akte, za katere je bilo že omenjeno, da se po praksi ustavnega sodišča ne štejejo za splošne upravne akte v slovenskem pravu. Poleg tega se nanaša tudi na akte, s katerimi se določa politika upravnega organa (policy statements), najpomembnejše pa je, da obsega tako akte, s katerimi se pravo izvršuje, kot tudi tiste, $\mathrm{s}$ katerimi se le interpretira.

Ta razlika je posebej pomembna za postopek sprejemanja. Ameriško pravo razlikuje, čeprav s precej nejasnostmi, med predpisi, s katerimi se ustvarja novo pravo (legislative rules), in tistimi, s katerimi se le interpretira (interpretive rules). Teorija poudarja, da je razlika vsebinska (ustvarjanje novega prava) in da so formalne razlike glede postopka sprejemanja in objave zgolj posledica te razlike. ${ }^{\mathbf{8}} \mathrm{Kljub}$ temu je praktično vsebinsko razlikovanje težavno, saj je težko ugotoviti, kdaj neki predpis zgolj

4 V primeru Bi-Metallic Investment Co. v. Colorado, 239 U.S. 441(1915) je Vrhovno sodišče ZDA jasno izrazilo, da lahko državljani varujejo svoje pravice $v$ primeru, ko uprava sprejema splošna pravila bodočega ravnanja, le s političnimi sredstvi; glej Strauss, Peter L.: Administrative Justice in the United States, 1989, str. 134-135.

55 U.S.C. (United States Code) ßß 551-559; zakon so pripravljali celih deset let in je bil tudi pozneje večkrat spreminjan in dopolnjevan.

6 Tako je oboje v APA zaobseženo z izrazom "agency action", ki vključuje tudi opustitev ravnanja; 5 U.S.C. B 551, para. 13.

7 “... agency statement of general or particular applicability and future effect designed to implement, interpret, or prescribe law or policy." 5 U.S.C. ß 551, para. 4.

8 Anthony, Robert. A.: "Interpretive" Rules, "Legislative" Rules and "Spurious" Rules: Lifting the Smog; The Administrative Law Journal 8/1994 No. 1, Washington College of Law; str. 6-15. 
tolmači zakonske določbe, kdaj pa jih izvršuje s tem, da ustvarja novo pravo. Sodišča zato pogosto sprejmejo stališče formalnega kriterija, da je "legislative rule" tisti dokument upravnega organa, ki je bil sprejet na predpisani način, ${ }^{\mathbf{9}}$ drugi dokumenti pa so "interpretive rule".

Razlika med obema vrstama je $\vee$ njunem pravnem učinkovanju pred sodiščem (kajti razumljivo je, da upravni organ oboje upošteva kot obvezujoče). "Legislative rule" ima moč zakona in ga mora sodišče upoštevati, razen če ga ne razveljavi pod pogoji, predpisanimi v APA, $\mathbf{1 0}$ medtem ko pomeni "interpretive rule" zgolj tolmačenje zakona, ki ga je oblikoval upravni organ in na katero sodišče sploh ni vezano. Čeprav je pojem "rule" v ameriškem pravu precej širši od splošnih upravnih aktov ali predpisov $\vee$ slovenskem, pa ni velike razlike med "legislative rule" in predpisom. Oba morata biti objavljena, upravni organ mora ravnati na podlagi zakonskega pooblastila, ${ }^{11}$ biti morata $v$ skladu z ustavo in zakonom ter imata obvezujočo moč prava. Te podobnosti nedvomno upravičujejo razmišljanje o morebitni podobnosti glede postopka sprejemanja, kjer so glede na sedanje stanje bistvene razlike.

Temeljna oblika sprejemanja "legislative rule" je t. i. postopek "notice and comment", pogosto imenovan tudi neformalni postopek. ${ }^{12}$ Nanaša se na vse tovrstne akte (ne pa na "interpretive rule" in "policy statement"), razen na tiste, ki se nanašajo na vojaške in zunanje zadeve, na notranja razmerja $v$ upravnem organu ter na premoženjske zadeve države (javno lastnino, posojila, dotacije ali pogodbe). APA vsebuje še splošno klavzulo, da ta postopek ni potreben tudi takrat, ko upravni organ iz utemeljenih razlogov (ki jih objavi hkrati s sprejetim splošnim aktom) odloči, da je postopek nesmotrn, nepotreben ali v nasprotju z javnim interesom.

$\checkmark$ okviru tega postopka mora upravni organ objaviti predlog splošnega akta $\vee$ posebni uradni publikaciji Federal Register, ki je namenjena tudi objavljanju sprejetih aktov. Če se akt nanaša le na določene osebe, je lahko predlog vročen le tem osebam. Za objavo ni nujno, da vsebuje neposreden tekst predloga splošnega akta (čeprav je to običajno), ampak zadošča jasno navedena vsebina. Poleg tega pa mora objava vsebovati navedbo časa in kraja ter narave postopka sprejemanja akta (pri nekaterih aktih mora biti izvedena javna obravnava) in zakonskega pooblastila za izdajo akta.

Z objavo se začne čas zbiranja pripomb in predlogov, ki je običajno 30 do 60 dni, čeprav $\vee$ zakonu ni določen. $V$ tem času sme kdorkoli upravnemu organu podati pisne pripombe, ki lahko vsebujejo mnenja, podatke in argumente, pri čemer lahko upravni organ omogoči tudi njihovo ustno predstavitev. Po preteku roka je upravni organ

9 Strauss, Peter L., delo pod opombo 9, str. 155-156; šele v novejšem času so sodišča začela izrecno upoštevati vsebinski kriterij, ki pa so ga postavila dokaj visoko - ustvarjanje novega prava je zgolj predpisovanje novih pravic in obveznosti; glej Anthony, R. A., delo pod opombo 10, str. 15.

105 U.S.C. ß 706; ti pogoji so naslednji: (A) da gre za arbitraren ali muhast predpis, zlorabo diskrecije ali da je drugače $v$ neskladju z zakonom; (B) da nasprotuje ustavi; (C) da pomeni prekoračitev delovnega področja in pooblastil organa; (D) da ni bil izdan na predpisan način; (E) da ni podprt z dokazi; (F) da je v nasprotju z dejstvi, ki jih ugotovi sodišče v morebitnem dokaznem postopku.

11 Vrhovno sodišče ZDA $v$ zadnjem času vedno striktneje zahteva izrecno pooblastilo, čeprav je lahko formulirano s precej splošnimi izrazi; glej Strauss, Peter L., delo pod opombo 9, str. 156.

12 APA, 5 U.S.C. ß 553 (a), (b). 


\section{Rajko Pirnat \\ Postopek sprejemanja predpisov}

dolžan proučiti relevantne pripombe in hkrati z objavo sprejetega akta tudi objaviti kratko splošno stališče o podlagi in namenu sprejetega akta. Upravni organi pogosto ponovijo objavo in postopek zbiranja pripomb ali neposredno odgovorijo posameznim zainteresiranim osebam ter jim omogočijo še dodatne pripombe, čeprav APA tega ne zahteva. ${ }^{13}$

Poseben problem tega postopka je vprašanje, kakšno dokumentacijo mora upravni organ ponuditi na ogled v času zbiranja pripomb. Leta 1967 je bil sprejet zakon o svobodi informiranja (Freedom of Information Act - dopolnjen leta 1974), ki je pravzaprav zelo kompleksna dopolnitev APA. ${ }^{14}$ Za postopek sprejemanja splošnih aktov je posebej pomembno, da mora upravni organ na zahtevo komurkoli omogočiti vpogled $\vee$ spise (record), kar lahko zavrne le $v$ primerih, naštetih $\vee$ zakonu, ki se $\vee$ glavnem nanašajo na varovanje tajnosti in zasebnosti. Zavrnitev vpogleda je podvržena sodnemu nadzoru, pri čemer sodišče ne odloča le o zakonitosti, ampak meritorno. Te zahteve so močno razširile obseg dokumentacije, ki jo je upravni organ dolžan dati na vpogled, kar je povzročilo, da so tovrstni postopki sprejemanja splošnih aktov postali dragi in nerodni. Običajna praksa je, da upravni organ organizira posebne prostore, $v$ katerih $v$ času zbiranja pripomb vsakomur omogoči prebiranje in kopiranje dokumentov, ki so po njegovem mnenju relevantni in ki jih zbere $v$ posebni mapi.

APA predvideva tudi t. i. formalni postopek sprejemanja splošnih aktov, imenovan tudi postopek "trial type". Ta se uporablja za "legislative rule", kadar poseben zakon zahteva, da upravni organ sprejme splošni akt na podlagi dokumentiranega spisa in zapisnika po izvedeni javni obravnavi. ${ }^{\mathbf{1 5}} \mathrm{V}$ tem primeru se splošni akt sprejema povsem enako kot posamični akti, saj se uporabljajo določbe APA, ki se nanašajo na posamične akte. To zlasti pomeni, da se postopka lahko udeležujejo le osebe, ki imajo lastnost stranke, ${ }^{16}$ na ustni javni obravnavi mora biti strankam omogočeno navajati dejstva, dokaze in druge izjave kakor tudi mnenja o dokazih in izjavah drugih strank ter upravnega organa. Splošni akt mora vsebovati podrobno obrazložitev, z navedbo pravnega temelja in dejstev, na katerih akt temelji. Ta postopek je neroden in sodišča zelo restriktivno tolmačijo zakone glede zahteve, da se splošni akt sprejme po formalnem postopku. Posledica tega je, da se tak postopek le redko uporablja, večinoma za določanje cen javnih služb.

$\checkmark$ zadnjem času se je zaradi velikega obsega sodnih postopkov, $\vee$ katerih fizične ali pravne osebe izpodbijajo zakonitost splošnih aktov (približno 80 \% vseh zveznih upravnih predpisov je napadenih pred sodiščem), razvil neformalni postopek, imenovan "regulatory negotiation"17 (kratko "regneg" - izdajanje splošnega akta s pogajanjem). V bistvu gre za dopolnitev postopka "notice and comment" s tem, da upravni organ ustanovi poseben odbor, na katerem je organ sam sicer predstavljen, vendar

13 Strauss, Peter L., delo pod opombo 9, str. 156.

14 Ta določitev se nanaša na $ß 552$.

15 "... to be made on the record after opportunity for an agency hearing."; izraz "record" ne obsega le zapisnika, ampak vso dokumentacijo spisa.

16 Kriteriji so v tem primeru vendarle blažji kot pri posamičnih aktih; glej Strauss, Peter L., delo pod opombo 9, str. 158

17 Negotiated Rulemaking Act iz leta 1990. 
ga vodi neodvisni posrednik (facilitator). Upravni organ mora objaviti svojo namero, da organizira tak postopek sprejemanja predpisa in omogočiti še drugim posameznikom ali interesnim skupinam, da zahtevajo udeležbo v odboru, čeprav jim organ tega ni dolžan dovoliti. Odbor pripravi osnutek akta (praviloma s soglasjem), vendar ga upravni organ ni dolžan upoštevati kot predlog za nadaljnji postopek. Seveda je potem treba izvesti še celotni postopek "notice and comment" (z nekaj izjemami), ki pa tako manj obremenjuje upravni organ. Izkušnje so pokazale, da pride do manjšega obsega izpodbijanja tako izdanih splošnih aktov pred sodiščem.

$\mathrm{Na}$ koncu je treba omeniti še to, da za "interpretive rule" in "policy statement" APA $\mathbf{1 8}$ ne zahteva drugega kot objavo, bodisi v uradni publikaciji Federal Register (za pomembnejše akte) ali $\vee$ lastni publikaciji upravnega organa. Pomembna je tudi določba APA, da noben akt upravnega organa ne more imeti negativnih posledic (adverse affect) za kogarkoli, če ni bil objavljen, pa je objava po zakonu obvezna.

$\checkmark$ celoti vzeto je mogoče ugotoviti, da so postopki sprejemanja splošnih aktov $v$ ameriškem pravu sčasoma postali vse bolj zapleteni, obsežni in težavni za upravne organe, da pa so hkrati učinkovit način javnega nadzora nad upravo in omogočajo večjo kakovost, včasih pa tudi večjo sprejemljivost splošnih upravnih aktov.

\section{Nekaj vprašanj postopka sprejemanja predpisov de lege ferenda}

\subsection{Sedanje stanje}

Slovensko pravo ne pozna nobenih splošnih pravil o sprejemanju upravnih predpisov. Edino, kar je mogoče na tem mestu omeniti, je nekaj zelo splošnih določb o sprejemanju predpisov vlade, vsebovanih v Poslovniku Vlade Republike Slovenije (Ur. I. RS, št. 43/01 in 23/02), ki pa se nanašajo na vsa gradiva vlade in ne le na predpise in seveda nikakor ne vključujejo javnosti. Res je sicer, da se $v$ praksi vse pogosteje dogaja, da pristojna ministrstva osnutke predpisov objavijo na domači strani ministrstva in zbirajo pripombe glede njih, vendar je postopek neobvezen.

Zakon o urejanju prostora (ZUreP-1, Ur. I. RS, št. 110/02) določa poseben postopek za sprejemanje prostorskih aktov, ki so pravno vzeto predpisi, čeprav je njihova pravna narava lahko sporna. Problem je, da nekateri med njimi po svoji vsebini v marsičem niso predpisi, saj ne določajo abstraktnih pravnih pravil. Zlasti je $v$ tem pogledu problem strategija (bodisi prostorskega razvoja Slovenije ali občine), ki določa različne cilje in izhodišča tega razvoja (37. in 57. člen ZUreP-1) ter zasnovo prostorskega razvoja. Ti cilji so seveda indikativno določeni in s strategijo samo po sebi ni nikomur naložena obveznost njihovega doseganja. Res pa je, da pomenijo njene določbe omejitev in usmeritev za t. i. izvedbene prostorske akte, zlasti pa občinski prostorski akti ne smejo biti $\vee$ nasprotju z državnimi (21. člen ZUreP-1); upoštevaje to in dejstvo, da so izvedbeni prostorski akti pravna podlaga za vsebino gradbenih dovoljenj, jih je treba šteti za predpise.

185 U.S.C. ß 552 (a). 


\section{Rajko Pirnat \\ Postopek sprejemanja predpisov}

Splošni postopek sprejemanja prostorskih aktov obsega izdelavo programa priprave prostorskega akta, kar dva sklica prostorske konference (pred sprejemom programa priprave prostorskega izvedbenega akta in pred javno razgrnitvijo), pridobitev smernic za načrtovanje od nosilcev urejanja prostora, javno razgrnitev najmanj za 30 dni, v času katere se opravi javna obravnava (glede na pripombe v javni obravnavi se javna razgrnitev in javna obravnava po potrebi ponovita), in njegov sprejem ter objavo. Posebna novost je prostorska konferenca, ki se $v$ bistvu loči od javne obravnave. Namen prostorske konference je pridobiti in uskladiti priporočila, usmeritve in interese določenih subjektov (28. člen ZUreP-1), ne zgolj zbrati pripombe, kot je to namen javne obravnave. Če pa naj bo tako usklajevanje učinkovito, mora zakon urediti postopek dela in odločanja prostorske konference, vključno z glasovanjem, jasno in določno urediti njeno sestavo za posamezno vrsto prostorskih aktov in način njenega vodenja. Ker tega ni, se bodo po mojem mnenju prostorske konference izrodile $v$ dodatne javne obravnave, kjer se ne bodo usklajevala stališča in interesi, ampak le zbirale morebiti tudi povsem kontradiktorne pripombe.

Običajen postopek sprejemanja drugih upravnih predpisov je povsem neformalen in obsega tak ali drugačen način priprave predpisa, največkrat tako, da ga pripravi ali vsaj obravnava neka delovna skupina, ali morebitno obravnavanje na kolegiju ministra in odločitev ministra o podpisu splošnega akta. Opozoriti je treba še na določbo 60 . člena Zakona o državni upravi (ZDU-1, Ur. I. RS, št. 52/02), po kateri morajo ministrstva pri pripravljanju predpisov in drugih aktov medsebojno sodelovati oziroma predhodno pridobiti mnenje drugih pristojnih ministrstev. Včasih zakon zahteva, da predpis izda minister ob soglasju drugega ministra, pri čemer odloči o morebitnem sporu med njima vlada (61. člen ZDU-1).

\subsection{Cilji postopka sprejemanja predpisov}

Če naj se predpiše splošen postopek sprejemanja upravnih predpisov, je najprej treba ugotoviti, kakšni naj bi bili razlogi za njegovo uvedbo in kakšne so njegove prednosti in težave. Kot nedvomno izhaja iz vsega dosedanjega razpravljanja, je glavni cilj takega postopka formalizirana vključitev javnosti vanj. Poleg splošnega učinka demokratizacije javne uprave prinese tak postopek gotovo še naslednje koristi:

- boljši vpogled upravnega organa v interese, ki jih bo predlagani predpis zadeval, in identifikacijo njihovih nosilcev;

- boljše spoznanje pozitivnih ali negativnih posledic, ki jih bo posameznim subjektom povzročil predlagani predpis;

- večje poznavanje dejstev (vključujoč tudi znanstvena spoznanja), ki so podlaga za predlagani predpis;

- oblikovanje morebitnih alternativnih možnih rešitev;

- iskanje novih argumentov za tako oz. drugačno rešitev ali proti njej.

Rezultat tega je verjetno boljša kakovost predpisov, večja sprejemljivost pri javnosti in s tem tudi njihova večja legitimnost. Seveda pa prinese tak postopek tudi 
težave, povezane zlasti z:

- večjimi stroški upravnih organov pri pripravi predpisov;

- večjim obsegom upravnega dela, ki je potreben za pripravo predpisa;

- daljšim časom, ki je potreben za oblikovanje in sprejem predpisa.

Menim, da koristi odtehtajo težave, čeprav je njihovo medsebojno razmerje treba upoštevati pri oblikovanju elementov takega splošnega postopka in poiskati ustrezno ravnotežje. Nedvomno pa je, da še tako strogo vztrajanje pri vsebinski zakonitosti predpisa ne more prinesti vseh prej navedenih koristi in zato tudi ne more nadomestiti uvedbe splošnega postopka sprejemanja predpisov.

\subsection{Nekaj idej za določitev postopka sprejemanja predpisov}

Pri iskanju elementov splošnega postopka sprejemanja upravnih predpisov je treba rešiti zlasti naslednja vprašanja:

a) na katere upravne predpise naj se nanaša in kakšne izjeme naj dopušča;

b) kaj naj vsebuje objava predlaganega predpisa in katero dokumentacijo mora upravni organ dopustiti na ogled zainteresiranim osebam;

c) kdo in v kolikšnem roku lahko daje pripombe;

d) kaj mora upravni organ narediti ob sprejemu predpisa.

Ad a. Če naj se oblikuje splošni postopek sprejemanja upravnih predpisov, se mora nanašati na vse predpise ( $v$ smislu navedb $v$ točki 2 tega prispevka) z morebitnimi izjemami. Druga, vendar bistveno slabša rešitev bi bila, da bi veljal tak postopek le za nekatere vrste predpisov, npr. uredbe vlade. Vendar se taka rešitev nikakor ne zdi dobra, ampak je treba urediti splošen postopek in predvideti izjeme. Te izjeme naj bi bile zlasti:

- uredbe z zakonsko močjo predsednika republike;

- predpisi s področja obrambe države in zunanjih zadev;

- predpisi, pri katerih bi bila njihova predhodna objava v nasprotju z namenom izdaje;

- predpisi, pri katerih je izvedba postopka iz utemeljenih razlogov nepotrebna ali nepraktična (potreba po hitri uveljavitvi predpisa, majhni in nebistveni učinki predpisa ipd.).

$\checkmark$ primerih iz 3. in 4. alineje bi moral upravni organ razloge, na katerih utemeljuje odstop od postopka sprejemanja predpisa, objaviti hkrati s sprejetim predpisom (verjetno bi bilo smiselno, da predstavljajo obvezno določbo $v$ samem besedilu predpisa, bodisi na začetku ali v prehodnih in končnih določbah) in bi jih ustavno sodišče lahko presojalo ob presoji ustavnosti in zakonitosti predpisa.

Ad b. Nedvomno je smiselno, da bi bila po vzoru postopka "notice and comment" $\checkmark$ ameriškem pravu tudi $v$ slovenskem temeljna elementa splošnega postopka sprejemanja predpisov objava in možnost dajanja pripomb. Objava naj bi obsegala navedbo zakonske podlage predpisa, razloge za izdajo predpisa, namen in cilje predpisa, besedilo predlaganega predpisa in njegovo kratko obrazložitev. Ti elementi so celo zahtevnejši kot $v$ ameriškem pravu, vendar $v$ nadaljevanju predlagam, da naj bi upravni organ ne bil dolžan dati na razpolago zainteresiranim osebam vse dokumentacije $v$ zvezi s pripravo 


\section{Rajko Pirnat \\ Postopek sprejemanja predpisov}

predpisa, tako kot to zahteva ameriški APA. ${ }^{19}$ Menim, da je primerneje predvideti kompleksnejšo in vseobsežno objavo, podobno objavi predloga zakona ter opustiti drago in organizacijsko težavno obveznost upravnega organa, da omogoči ogled in razmnoževanje dokumentacije.

Posebno vprašanje je, kdaj naj pride do objave. Gotovo je smotrno, da se najprej opravi ves postopek oblikovanja in obravnave predpisa $v$ upravnem organu, vključno z morebitnim delom delovne skupine. Verjetno je tudi smiselno, da se pred tem opravi t. i. medresorsko usklajevanje po omenjenem 50. členu zakona o upravi. ${ }^{20}$ Če pa zakon zahteva, da izda upravni organ predpis s soglasjem drugega organa, je mogoče to soglasje pridobiti seveda šele po izvedbi postopka z objavo in pridobivanjem pripomb. Glede uredb vlade je mogoče oceniti, da naj bi se postopek objave in pridobivanja pripomb izvedel po opravljeni obravnavi na odborih vlade.

Glede mesta objave je najmanj treba zahtevati, da se objavi na domači strani ministrstva ali vlade, hkrati pa se uvedba postopka zbiranja pripomb objavi v sredstvih javnega obveščanja. Razmisliti bi bilo mogoče tudi o ustanovitvi posebne publikacije vlade, namenjene objavljanju predlogov predpisov, saj Poročevalec Državnega zbora $\mathrm{RS}$ za to ni primeren zaradi načela delitve oblasti, Uradni list RS pa je predviden le za objavljanje sprejetih aktov. Vendar je to vprašanje potrebnih sredstev in vsaj ob uvedbi postopka sprejemanja predpisov nikakor ni nujno.

Ad c. Z objavo naj bi začel teči rok (ne krajši kot 30 in ne daljši kot 90 dni), določen $\checkmark$ objavi, $v$ katerem je mogoče dajati pripombe in predloge $\mathrm{k}$ predlaganemu predpisu. Menim, da ne bi bilo smiselno, da bi bil za dajanje pripomb potreben kakšen poseben izkazan pravni interes, temveč naj bo to omogočeno vsakomur. Zahtevati je le treba, da morajo biti pripombe poslane pismeno upravnemu organu $v$ določenem roku.

Neprimerno bi bilo od organa zahtevati, da odgovori na posamezne pripombe ali da daje dodatna pojasnila in informacije, najsi so še tako utemeljene. Seveda pa je povsem mogoče dopustiti, da upravni organ to stori, če meni, da to pripomore k razjasnitvi položaja.

Ad d. Po prenehanju objave je mogoče upravnemu organu prepustiti odločitev, kaj bo storil: povsem opustil predpis (razen če ga seveda k izdaji akta ne zavezuje izvršilna klavzula), ponovno opravil obravnavo $v$ okviru organa ali pa celo potem ponovno objavil predlog. Kar bi bilo smiselno zahtevati, pa je, da upravni organ hkrati z objavo sprejetega predpisa objavi tudi povzetek najpomembnejših pripomb in predlogov ter razloge, zaradi katerih jih je sprejel ali zavrnil. Te objave seveda ni mogoče opraviti skupaj z objavo predpisa $\vee$ Uradnem listu RS, ampak je treba zahtevati, da se ta povzetek objavi v prej omenjeni posebni publikaciji vlade najkasneje do dneva uveljavitve predpisa.

19 Zelo zahtevne določbe APA, uvedene s Freedom of Information Act iz leta 1974, o dajanju dokumentacije na razpolago so pravzaprav rezultat posebnih zgodovinskih okoliščin $v$ ZDA, povezanih z afero Watergate, in po oceni resnih analitikov ( $v$ nadaljevanju citirani avtor je sodnik Vrhovnega sodišča ZDA) hromijo delovanje uprave, so predrage in omogočajo zlorabo pravice do obveščenosti; glej Scalia, Antonin: The Freedom of Information Act Has No Clothes, Regulation 15/1982, str. 15-19. 20 Taka je tudi praksa v ameriškem pravu, ki jo navaja A Guide to Federal Agency Rulemaking, ACUS 1991, str. 250-251. 
Ti elementi splošnega postopka sprejemanja predpisa lahko pomenijo le minimum, ki ga morajo spoštovati upravni organi, in gotovo je mogoče dopustiti, da upravni organi izvedejo še druge korake v postopku sprejemanja predpisa, kadar je to primerno: javne predstavitve in obravnave, ustanovitev posebnih posvetovalnih ali pogajalskih komisij ipd., vse zaradi večje vključitve javnosti v postopek sprejemanja predpisa.

Razumljivo je tudi, da bi bilo treba kakršnekoli rešitve, sploh odločitev za uvedbo takega postopka, skrbno pretehtati, zlasti pa tudi preizkusiti njene učinke. Nedvomno bi ga bilo smotrno najprej preizkusiti na nekaj primerih splošnih aktov (zlasti tistih, ki imajo pomembnejše učinke) in šele na podlagi teh izkušenj uvesti tak postopek kot obveznost.

\subsection{Vprašanje nadzora nad procesno zakonitostjo predpisov}

Postopek sprejemanja predpisov mora $\vee$ celoti in vseh podrobnostih določiti zakon. Noben podzakonski predpis seveda ne more določati obveznosti postopka sprejemanja drugega predpisa, saj ustava ne zahteva, da bi bili podzakonski predpisi med seboj v skladu.

Predpis, ki ne bi bil v skladu z zakonom, urejajočim postopek sprejemanja predpisov, bi seveda bil nezakonit. Čeprav gre za procesno nezakonitost, je za njeno ugotavljanje $\vee$ celoti mogoče uporabiti postopek ocene ustavnosti in zakonitosti pred ustavnim sodiščem. Omeniti je treba, da je ustavno sodišče procesno zakonitost prostorskih izvedbenih aktov že večkrat ocenjevalo in npr. štelo prostorski izvedbeni akt, $v$ katerem prebivalcem prizadete krajevne skupnosti ni bilo omogočeno sodelovanje na javni obravnavi in dajanje pripomb, za nezakonit. 21

Kriterije zahtevane procesne zakonitosti bi bilo seveda treba na novo oblikovati, vendar je pri tem nedvomno treba izhajati iz pojma "bistvena kršitev postopka", kot je oblikovan v različnih postopkovnih zakonih. Le kršitev, ki bi lahko pripeljala do drugačne vsebine predpisa, naj bi bila temelj njegove razveljavitve ali odprave.

Edino vprašanje tu je morda vprašanje časa. Uvedba postopka ocene ustavnosti in zakonitosti predpisa po veljavni ureditvi seveda ni vezana na noben rok, kar je za vsebinsko zakonitost seveda razumljivo. Glede procesne zakonitosti pa je treba razmisliti, ali ne bi kazalo to možnost vezati na rok po objavi predpisa (npr. nekaj mesecev). Čeprav seveda ne gre za vprašanje pravnomočnosti, saj se s predpisom (vsaj praviloma) ne urejajo posamična razmerja in v njih oblikujejo pravice in obveznosti, pa vseeno dvomim, da bi bilo smiselno možnost izpodbijanja predpisa zaradi procesnih napak $v$ postopku njenega sprejemanja časovno omejiti, saj mora pravo od oseb, ki želijo sodelovati $\vee$ postopku z dajanjem pripomb pričakovati določeno skrbnost. Poleg tega bi lahko bilo s temi postopki ustavno sodišče zelo obremenjeno, če ne bi bili časovno omejeni, saj je možen krog oseb, ki bi izkazale pravni interes za vložitev pobude za uvedbo postopka ocene ustavnosti in zakonitosti, lahko precej širok.

$21 \mathrm{U}-\mathrm{I}-126 / 93$ 
Rajko Pirnat

Postopek sprejemanja predpisov

Prof. dr. Rajko Pirnat je doktor pravnih znanosti in redni profesor za javno upravo in upravno pravo na Pravni fakulteti Univerze $v$ Ljubljani. Je nosilec večjega števila raziskovalnih projektov $v$ okviru Inštituta za javno upravo pri Pravni fakulteti v Ljubljani, sodeloval pa je tudi v več mednarodnih projektih programa PHARE.

\section{SUMMARY}

\section{Procedure for Adoption of Regulations}

Key words: elements of adoption of administrative regulations, comparativelegal procedural aspects, procedure of adoption of spatial planning acts

The author establishes that the volume of regulatory activity of administration is on the increase also in Slovenia. In relation to this, he especially emphasises the increase in the volume of this activity in the time of integration of the European law into the Slovene legal system. Therefore, he believes that due to the increasing volume of this activity, the question concerning the adoption of regulations in this area has lately been very relevant also in Slovenia.

When discussing the question of legal regulation of this procedure, he takes as a basis the principle of a democratic state and the principle of separation of powers. According to the author, it is possible to ensure the legitimacy of administrative regulations by transferring the political process, which is characteristic of the adoption of laws, also to the adoption of administrative regulations. He indicates limitations and possibilities of legal regulation of the procedure for adoption of administrative regulations according to the principle of separation of powers.

Further on, he gives a concise presentation of the American regulation of adoption of federal administrative regulations. The presentation lays emphasis on the so-called "notice and comment" procedure, called also informal procedure. Within the framework of this procedure, the administrative body has to publish a proposal of a general act in a special official publication Federal Register, which is intended also for publication of adopted acts, and thus allow the participation of the public in this procedure.

In the second part, the author discusses some fundamental elements of a possible general procedure for adoption of administrative regulations in Slovenia. With regard to this, he emphasises that the goal of such procedure is formalised integration of the public into this procedure.

According to the author, it is especially necessary to provide answers to the following questions when designing a general procedure for adoption of administrative regulations:

- Which administrative regulations should it refer to and which exceptions should it allow? 
- What should a publication of a proposed regulation contain and which documentation should an administrative body allow to be examined by the interested parties?

-Who and to what extent can make comments?

-What should an administrative body do at the adoption of a regulation?

In the article, the author also draws attention to the question of control over procedural legitimacy of administrative regulations. 